\title{
Vine landscapes in Crimea: evolution, problems, prospects
}

\begin{abstract}
The conditions and factors of development of the vine landscapes in Crimea and their evolution are considered for the ancient, medieval, imperial, Soviet (first and second halves of the $20^{\text {th }}$ century), and postSoviet periods. The characteristics of the vineyard landscape zones (South Coast, Foothills and Steppe) are presented. Having reached their maximum areas in the period 1955-1970, the area of the vineyards in Crimea decreased steadily until 2017 . The main causes of degradation were the spread of phylloxera, the campaign against alcoholism in 1985, the deterioration of sales after the collapse of the USSR, and the ineffective system of cultivation technology. The current ways of reviving grape landscapes - the introduction of innovative methods of farming, greening and cluster forms of viticulture and winemaking - are addressed.
\end{abstract}

Keywords

Crimea $\cdot$ vineyard landscapes $\cdot$ cultural landscapes $\bullet$ evolution $\bullet$ cultura heritage

(C) University of Warsaw - Faculty of Geography and Regional Studies

Introduction

The vine landscapes of Crimea are an integral part of its cultural landscapes, which have a history that spans several millennia. Viticulture is a priority direction for the development of the economy of this region, rich in traditions and experience in the cultivation of grapes. The grapes grown in Crimea are distinguished by high quality taste and good capacity for storage and transportation. The liqueur wines made from these grapes Muscat white, Muscat pink and Muscat black technical varieties - are among the best in the world.

The well-known scientific school of viticulture and winemaking was formed in Crimea. The role of different natural factors in the functioning of the vine landscapes has been shown in the works of Akimtseva (1946), Bolgarov (1960), Negrul and Krylatov (1964), Blagonravova and Shcherbakova (1963), Fursa (1977), Davitaya (1981), Khachaturyan and Gavrilov (1985), Kazantseva and Fursa (1985), and Dragan (1990). The directions of optimization of Crimean viticulture and winemaking in different periods of time were investigated by Buzni (1929), Ponomarev, Pargulov and Chernjavskij (1975), Rybintsev (1998), Matchina and Buzni (1999), Dzhenev and Antipov (1999), Avidzba (2000), Avidzba and Cheremisina (2003), and Dikan (2013).

The topicality of vine landscape scientific research carried out not only by Crimean scholars but also by the international community is a result of the problems of studying the conservation of the landscapes. This task was put forward by the Council of Europe 2000, the European Landscape Convention and UNESCO 1972, and the Convention concerning the Protection of the World Cultural and Natural Heritage.

The aim of this article is to study the evolution of vine landscapes in Crimea, to reveal the current problems and to identify directions of perspective development.
Katerina Pozachenyuk ${ }^{1}$, Irina Yakovenko²

'Department of Physical Geography, Oceanology and Landscape Science, Crimean Federal V.I. Vernadsky University, Simferopol e-mail: pozachenyuk@gmail.com

2Department of Tourism, Crimean Federal V.I. Vernadsky University, Simferopol e-mail: yakovenko-tnu@ya.ru

Received: 17 January 2018 Accepted: 7 May 2018
Sources and methods of research

Bibliographic, statistical and cartographic sources were involved in the research. The borders on the map of the modern zones of vine landscapes in Crimea were defined using the existing geographical zoning of Crimea. To study the dynamics of the vineyard area and their productivity, data from the Ministry of Agriculture of R. Crimea was used.

Environmental features and viticulture development

Crimea has a favourable natural potential for the cultivation of grapes and the formation of vine landscapes (ed. Pozachenjuk 2009). The main climatic factor that determines the possibility of cultivation is the temperature during the vegetation period. In Crimea, the territory from 46 to $44^{\circ}$ North latitude, and from 33 to $37^{\circ}$ East longitude, is appropriate for grape cultivation. The abundance of sunshine, and the long warm period with an average daily temperature above $10^{\circ} \mathrm{C}$ for 180 days in the North and 210 days in the South of Crimea, create favourable conditions for growing grapes of table and technical varieties (Ved' 2003).

The significant properties of the soils are the mechanical composition, the soil power and unconsolidated deposits, the moisture supply, the salt regime, and so on. In this respect, most soils in Crimea - chernozems/kastanoze, kastanozems, anthrosols, and partly sod-carbonate soils - are suitable for the formation of vine landscapes. The hydromorphic plains of Crimea with halophytic saline and chestnut soils are the limiting factor of the geographic vine landscape distribution. The Crimean Sivash area differs notably, with a near total absence of vineyards (eds. Skvortsova \& Dragan 1990).

The relief of Crimea is also an important factor in the development of vine landscapes. The Crimean Mountains limit 


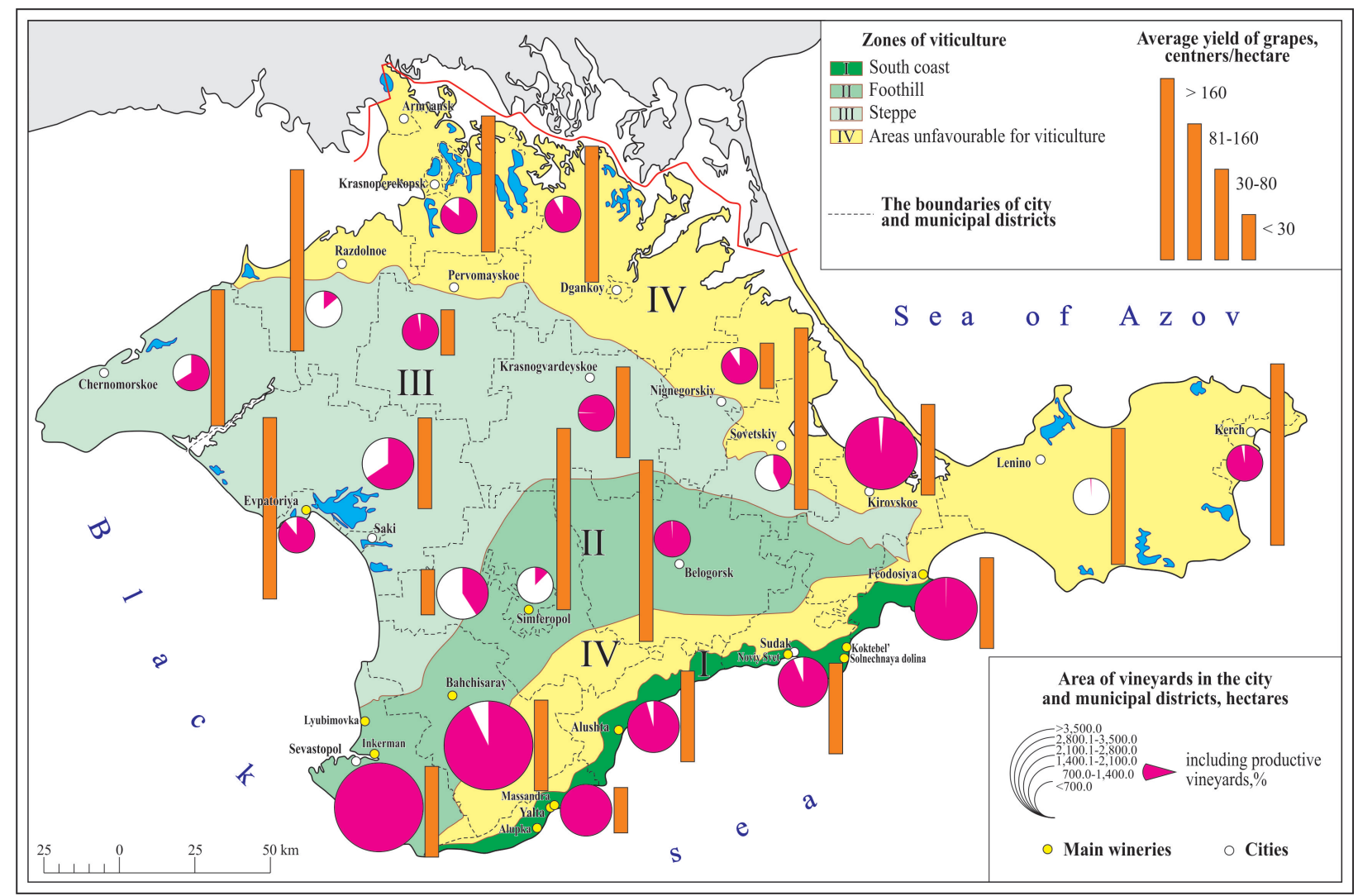

Figure 1. Zones of vine landscapes in Crimea

Source: Author's map based on information from the Ministry of Agriculture of R. Crimea, 2017

their spreading up to a height of $700 \mathrm{~m}$. The lower boundary of the vine landscape formation reaches $70-180 \mathrm{~m}$. Orientation in the mountainous parts of Crimea has a different effect on the functioning of the vineyards. The Northern, North-Western and North-Eastern slopes are not good enough for growing most grapes, while the slopes with southern expositions are favourable. The mountain valleys, because of the dominance of mountain-valley winds, fog and frost, lead to disease of the vineyards and reduce their productivity. The Black Sea has a positive effect on vine landscape formation. Especially positive conditions occur along the South coast, where the mountains protect these landscapes from the cold North-East winds, and the grapes are grown without the protection of bushes in the winter. The favourable influence of the sea also affects the West coast from Balaklava to the Tarkhankut Peninsula, where grapes are cultivated without cover during the winter. At the same time, the soil salinity of coastal areas reduces the quality and yield of grapes in the breeze zone.

The modern geography of industrial viticulture coincides with the ancient centres of reference, where the grape is an important element of the trophic culture, and its cultivation is a component of targeted farming systems. In 2000, perennial plantations (vineyards) accounted for $6.2 \%$ of the total land area of Crimea.

\section{Landscapes of the vineyard zones of Crimea}

The territory of the Crimean Peninsula's climatic conditions for the formation of vine landscapes can be divided into four zones: the South Coast (I), the Foothills (II) and the Steppe (III, IV) (Figure 1).
Grape landscapes of Crimea were formed in the following natural zones (Major Habitat Zones) of Crimea (Pozachenyuk 2009): - $\quad$ within the southern macroslope of the Crimean Mountains the Submediterranean Vegetation of the South Cost (I - see Figure 1), partially in the forests of the Southern Slope (IV - see Figure 1);

- $\quad$ in the plains of Crimea - the True Steppe (III - see Figure 1) and partially in the Semi-desert Steppe and Saline Lands (prisivashe, IV - see Figure 1), as well as the Semi-desert Steppe and Saline Lands of the Kerch Peninsula (Kerch Peninsula, IV - see Figure 1);

- in the foothill and mountain areas of Crimea - the Premontane Forest Steppe (II - see Figure 1), partially in the forests of the Northern Slope (IV - see Figure 1).

The grape formation landscapes of Crimea have their own peculiarity in each natural zone (Tab. 1).

The South coast area of vineyards covers the Southern coast of Crimea (Figure 2). The natural conditions of this area are extremely favourable for maturing non-covered grapes, cultivating extra-early, late and very late varieties of grapes with a high sugar content (Tab. 1). The soils of the zone are highlyaltered anthrosols, so-called slate-anthrosols. River valleys have more fertile soils and the grape harvest is larger, especially when watering.

This zone is characterized by the planting of square vineyards in river valleys - ordinary (trellis). The location of roads and the shape of the site affect the choice of the direction of the rows of grapes. The density of vine planting depends mainly on the climatic and soil conditions of the area. On the steep and stony 
MISCELLANEA GEOGRAPHICA - REGIONAL STUDIES ON DEVELOPMENT

Vol. 22 • No. 2 • 2018 • pp. 102-108 • ISSN: 2084-6118 • DOI: 10.2478/mgrsd-2018-0012

Table 1. Climatic resources of the zones of vine landscapes in Crimea

\begin{tabular}{|c|c|c|c|}
\hline \multirow[t]{2}{*}{ Characteristics } & \multicolumn{3}{|c|}{ Zone } \\
\hline & South Coast & Foothills & Steppe \\
\hline $\begin{array}{l}\text { Amount of active } \mathrm{t}^{\circ} \mathrm{C} \text { above } \\
\qquad 10^{\circ} \mathrm{C}\end{array}$ & $3,540-4,195$ & $2,945-3,763$ & $3,215-3,580$ \\
\hline $\begin{array}{l}\text { Average amount of } \\
\text { precipitation, mm: } \\
\text { November-March } \\
\text { April-October }\end{array}$ & $\begin{array}{l}123-318 \\
189-269 \\
\end{array}$ & $\begin{array}{l}147-209 \\
225-305\end{array}$ & $\begin{array}{l}127-174 \\
183-301\end{array}$ \\
\hline Absolute minimum $\mathrm{t}^{\circ} \mathrm{C}$ & $-15-(-25)$ & $-28-(-35)$ & $27-(-33)$ \\
\hline Average annual $t^{\circ} \mathrm{C}$ & $12.1-13.9$ & $9.7-11.7$ & $9.9-12.0$ \\
\hline Soils & Anthrosols & Kastanozems & $\begin{array}{l}\text { Chernozems/kastanoze } \\
\text { Kastanozems, Calcisols }\end{array}$ \\
\hline Habitat Zones & $\begin{array}{l}\text { Submediterranean Vegetation } \\
\text { of the South Cost, } \\
\text { Forests of the Southern Slope }\end{array}$ & $\begin{array}{l}\text { Premontane Forest Steppe, } \\
\text { Forests of the Northern Slope }\end{array}$ & $\begin{array}{c}\text { Semi-desert Steppe and Saline } \\
\text { Lands, } \\
\text { True Steppe, } \\
\text { Semi-desert Steppe and Saline } \\
\text { Lands of the Kerch Peninsula }\end{array}$ \\
\hline Vineyards & $\begin{array}{c}\text { Vineyards indomitable; square } \\
\text { planting vineyards; } \\
\text { trenching to a depth of } 1-1.25 \\
\mathrm{~m}\end{array}$ & $\begin{array}{c}\text { Mostly covered; } \\
\text { square and ordinary planting } \\
\text { vineyards; } \\
\text { trenching to a depth of } 0.70 \\
-1.25 \mathrm{~m}\end{array}$ & $\begin{array}{c}\text { Covered, in some areas } \\
\text { neucrylate; ordinary planting } \\
\text { vineyards } \\
\text { (trellis); trenching to a depth of } \\
1-0.70 \mathrm{~m}\end{array}$ \\
\hline
\end{tabular}

Source: Table compiled by the authors based on materials from the Conception of Viticulture and Winemaking Strategy in the Republic of Crimea, 2014

slopes, where bushes have a relatively weak growth (southern coast of Crimea), a square planting with a distance of 1.06 metres between one bush and the next is used. 8,927 bushes are placed in one hectare. On the gentle slopes, which have more rich soils, the distance between bushes increases to $1.42 \mathrm{~m}$, giving 4,975 bushes per hectare.

This area produces the best Muscat wines, Port wines and Madeira wines of all post-Soviet countries.

The Foothill area geographically coincides with the foothills of the main ridge of the Crimean Mountains. The covered vine landscapes, early ripening for the production of cognac wine materials and champagne, are on the larger forest-steppe of the foothills. Good table grapes are grown here as well. In the Western part of the foothills, where the landscape is formed under the influence of the south-westerly warm air masses blowing from the sea, the non-covered vineyards of technical grapes with a different maturing time are grown. The best wine material for champagne and fine table wines is found here, as well as grapes for good quality strong and dessert wines and juices.

When planting vineyards, the slopes are often terraced. This method of planting grapes in Crimea was introduced by the ancient Greeks. In river valleys and mountain terraces the ordinary (trellis) planting of vineyards prevails, and on the slopes the square method is used. In the grape landscapes in the mountainous part of Crimea, the bushes are typically 'cupped' in shape.

The Steppe zone coincides geographically with the majority of the Crimean plain. In its central part, covered vine landscapes of table grape varieties with early ripening are formed.

In the Crimean plain, the soils are more fertile, grape bushes have strong growth and are planted using the rarer ordinary (trellis) method. The distance between the rows is 2 metres, with a row of 1.5 metres between the bushes, and 3,333 bushes per hectare. This zone of Crimea, in comparison with other zones, is colder, so for good grape ripening the earth needs to be warmed

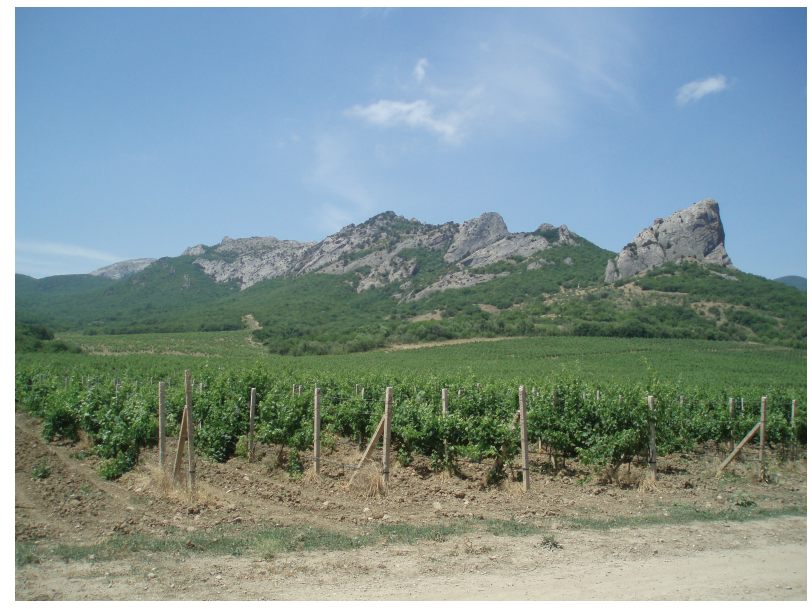

Figure 2. Cultural vine landscapes of the South Coast zone. Photo by authors

by the sun to a greater extent: the vineyard rows often run from North to South (with rows being exposed to the hottest rays at noon). This vineyard orientation is often used in the warmer locations on the South coast of Crimea, as in the hottest hours of the day, the bushes shade each other or receive side lighting.

The grape landscapes of the Crimean plain are characterized by the so-called 'bilateral Guyot cordon' form of bushes. The conditions of the area are favourable for the production of cognac and sparkling wine, strong and dessert wines. In the western part of the Steppe zone, due to the warming effect of the sea, noncovered and covered vineyards of early and medium ripening are formed. Their materials can be used for producing white wine 
of all types, strong white and red table wines, ordinary dessert wines and vintage port.

Vine landscapes of Crimea's evolution

Throughout history, the scale of Crimean viticulture, its geographic structure and the role in the societal development of the Crimean region have changed. Six stages can be distinguished in the evolution of vine landscapes in Crimea:

I. The antique period. Viticulture and winemaking appeared in Crimea between the $9^{\text {th }}$ and $5^{\text {th }}$ centuries $B C$ when ancient peoples - the Cimmerians and the Tauri-inhabited the Peninsula. In the period of the Greek colonization of the Northern Black Sea area $\left(8^{\text {th }}\right.$ to $6^{\text {th }}$ centuries $B C$ ), urban settlements (Chersonese, Panticapaeum, Tiritaka, etc.) appeared in Crimea. They were notable for their developed vine-growing and winemaking culture.

Colonists from Greece brought the vine to Crimea and introduced technology for the cultivation of grapes, which allowed crop quality to be improved - cutting leaves, tying up vines, late vintage and other methods. Wine in amphorae was an important article of foreign trade from Greek cities in Crimea with the cities of the Black Sea and the Mediterranean area. Almost all the territory of Chersonese (present-day Sevastopol) in the $4^{\text {th }}$ century BC was divided into 400 so-called clares of 30 hectares each, where vineyards and wineries were located (Kontseptsiya strategii razvitiya 2014). The loss of areas in North-Western Crimea as a result of Scythian expansion in the $2^{\text {nd }}$ century BC led to changes in the structure of agricultural production, the reduction of the vine landscapes and the increase of grain crop areas (ed. Petrova 2010).

II. The medieval period. When the Golden Horde invaded the territory of Tavria Kherson (medieval Chersonesos) in 1395$1396 \mathrm{AD}$, the most important centre of viticulture was burned and viticulture moved to the cave cities of southwest Crimea Kachi-Kalon, Tepe-Kermen, Eski-Kermen, and the Principality of Mangup Caleh.

The revival of viticulture in the region of Sudak (medieval Surozh, Sugdea), and in the $15^{\text {th }}$ century on the southern coast of the Peninsula, began with the arrival of the Genoese. The main areas of the spread of vineyards were coastal areas - Kefe (Feodosiya), the territory between Gurzuf and Alushta, Sudak, Inkerman and Balaclava (Bolgarov 1960). In the period of the Crimean khanate, viticulture and winemaking were cultivated by local residents - Greeks and Karaites. Despite the Koran's ban on producing and consuming wine, the Crimean Khan Shagin Ghiray received a tribute from Sudak and Mangup vineyards (ed. Petrova 2010). However, on the whole, in the Muslim Crimea, viticulture and winemaking did not play a major economic role. III. The tsarist period. The Russo-Turkish war (18 ${ }^{\text {th }}$ century AD) led to an almost complete destruction of the vineyards on the southern coast of Crimea. A new upsurge in the development of viticulture began with the annexation of Crimea by Russia in 1783 and Catherine the Great's policy of donating and selling Crimean lands for their accelerated development. As a result, Count G.A. Potemkin had a new plantation of technical grapes laid in the valleys and mountain slopes of the southern coast with Pinot Gris, Tokay and other vines imported from abroad. Count M.S. Vorontsov, who created new vineyards in his South coast estates at Alupka, Al-Danil, Massandra and Gurzuf, played an important role in developing this industry (Istorija vinogradarstva v Krymu 2018).

A government decree of 14 September 1828 approved the inheritance rights for the cultivation of vineyards. Preferential taxes to the treasury, cash awards and medals for success in viticulture were introduced (Zaharova 2005). In the 1930s, in the area of Alushta-Feodosiya-Kerch, more than 3 million vines were grown (Bolgarov 1960). Most of them were formed from varieties imported from Europe and local wine varieties such as Cabernet, Riesling, Pinot, Kokur, Chasselas, Pedro Ximenez, Semillon, Claret, Tokai, Zand, Grenache and Muscats. The scientific institution 'Magarach' (Yalta), founded with the participation of Count Vorontsov, has engaged in variety testing, breeding new varieties of vines and training vine-growers and winemakers. During the Crimean war of 1853-1856, grape plantations in Sevastopol and Bakhchisarai were badly damaged and some were uprooted.

Thanks to Prince L. S. Golitsyn's idea on the development of the production of sparkling wines in the 'New world' estate (South-Eastern Crimea), new vineyards were installed. In 1889 in M.S. Vorontsov's estates, the 'Massandra' winery was organised and new approaches were adopted for the management of viticulture and the methods of combating grape diseases, such as oidium and mildew. However, problems arose in terms of planting diversity, a large proportion of old vineyards, and the lack of fertilizers, which resulted in relatively low yields and the rapid damage of bushes.

In 1908, the total area of vineyards on the Peninsula amounted to 9,400 hectares, corresponding to $6^{\text {th }}$ position among the 11 major agricultural crops. In 1915, the export of fresh table grapes to St. Petersburg, Moscow and other Russian cities reached a record high $-1,277.000$ tons (Buzni 1929). However, more than $60 \%$ of the vineyards were run by small farms using primitive grape processing methods. As a result of the First World War followed by the Civil War, the area of vineyards decreased to 5,400 hectares and the yield capacity fell to 6.9 centner per ha (Ponomarev et al. 1975).

IV. The Soviet period (the first half of the $20^{\text {th }}$ century). During the 1920s and 1930s, the nationalization of estates was carried out. Cooperative economic associations ('Yuzhsovhos', later 'Crimsadvintrest', etc.) were organised. Due to the financial and technical assistance of the State, the total area of vineyards increased from 4,800 hectares in 1922 to 11,800 hectares in 1940, with 99.8 per cent of all vineyards falling under cooperative ownership and only $0.2 \%$ remaining the personal plots of the farmers (Istorija vinogradarstva $v$ Krymu 2018). The large increase in vineyard areas and grape harvests can also be explained by the improvement of new agricultural machinery methods. Great damage was caused to the vineyards of Crimea during the Second World War: more than 4,000 hectares were destroyed, and the remainder of vineyards were thinned out by $30-40 \%$ (Bolgarov 1960).

V. The Soviet period (the second half of the $20^{\text {th }}$ century). The period 1955-1970 was the heyday of Crimean vine-growing and winemaking. The total area of vineyards reached a record level in 1959 (152,500 ha), and the area of fruit-bearing vineyards increased to 88,200 ha in 1970 (Figure 3). The largest grape harvest was collected in 1976 (661,500 tons) (Fursa 1977). In addition to the traditional areas of viticulture and winemaking, the Sevastopol and Steppe wine areas were formed.

The construction of numerous factories of primary winemaking, located as close as possible to the source area, contributed to the widespread development of viticulture. The cultivation and processing of grapes during this period was considered a priority branch of the national economy of Crimea. The share of the revenues from the sale of grapes among agricultural products increased from $18.2 \%$ in 1961 to $22.5 \%$ in 1970; the level of profitability in 1970 reached $85.7 \%$ (Narodnoe hozjajstvo Krymskoj oblasti 1977). The monocentric management model was entrenched in the grape and wine sector of the region. Krymsovkhozvintrest, which consolidated 109 specialized companies and more than $50 \%$ of the orchards and vineyards in Crimea, coordinated the production and bilateral Guyot, as well as grape processing, supply and marketing. The total number of employees in the system was 63,000 people, and 
Krymsovkhozvintrest provided up to $65 \%$ of revenue in the budget of Crimea.

Since the mid-1970s, destructive phenomena began to occur in Crimean viticulture. Significant damage was done by phylloxera. Valuable vineyards were uprooted as a result of this pest, and only a small part of them were inoculated. An extremely negative role was played by the Communist Party Resolution of 7 May 1985 'On measures of overcoming drunkenness and alcoholism'. Large areas of vineyards were destroyed in the realisation of this Resolution. The total area of vineyards in Crimea decreased by 53.6\% between 1970 and 1996 .

VI. The post-Soviet period. The process of reforming the regional economy, including the grape and wine complex of Crimea, was accompanied by a reduction in the share of state ownership and an increase in private and collective ownership, as well as the deconcentration of land use and production. The main cause of degradation was the ineffective system of cultivation technology. Krymsovkhozvintrest disintegrated in 2006 , and its plantations became the property of numerous jointstock companies.

During the period 1990-2000, the grape and wine complex of Crimea remained unattractive for Ukrainian and foreign private investment. Among the few examples of foreign investment is the French company 'L'Empire du Vin' LLC, which established the 'Crimean Wine House' enterprise in 2004 (South-Eastern Crimea). As an experiment, 14 hectares of vineyards were laid with a drip irrigation system; new vineyards were planted and certified organic seedlings from France and Serbia were used.

\section{State, problems and prospects}

The state of Crimean viticulture by 2016 can be evaluated as stressful. The total area of vineyards in the Republic of Crimea and Sevastopol city had decreased to 22,800 hectares. The area of vineyards has grown from 17,090 hectares in 2014 to 18,500 hectares in 2016. 67 organisations are involved in the commercial production of grapes (Ministerstvo Sel'skogo Hozjajstva Respubliki Krym 2017).

For joint and individual enterprises, plantations with a small area have prevailed. $71.4 \%$ of these entrepreneurs have vineyard areas of less than 100 ha. The largest vineyard owners are the organisations with their own wineries included in the structure: the federal state unitary enterprise 'Massandra' (Yalta, 3,658.1 hectares of vineyards), 'Stary Krim' JSC (Kirovsky region, 1,092.9 ha), and 'Koktebel factory of chateau wines' LLC (Feodosia, 1,078.8 ha).

Cultural factors have had a particular influence on the viniculture industry of Crimea. Thus, the area of vineyards belonging to the Crimean Tatars is $2,551.52$ hectares $(14.6 \%$ of the total area); mainly table grapes are grown. Crimean Tatars are not represented in winemaking due to religious restrictions.

Grapes in Crimea are cultivated mainly in vaccinated inoculated open culture. The system is the following: a vertical trellis (the most common form), a mostly horizontal cordon of one or both sides on the medium and high trunk, and a planting scheme of $3 \mathrm{~m} \times 1.5 \mathrm{~m}$. Irrigated plantations make up $24 \%$ of the total vineyard area, but not more than $17 \%$ with drip irrigation. The water availability factor is a determinant of the yield and the gross grape harvest. The average annual grape production is $90,000-100,000$ tons with an average yield of 51 centners/ hectare. But in 2014, Ukraine's refusal to supply water to the North Crimean canal and the long summer drought led to a reduction in harvesting to 70,000 tons with an average yield of 43.4 centners/hectare. The age of the vineyards necessitates their systematic renewal (Figure 4).

Crimea's specialization is the cultivation of technical grape varieties, which account for $83 \%$ of the total area. Along with the

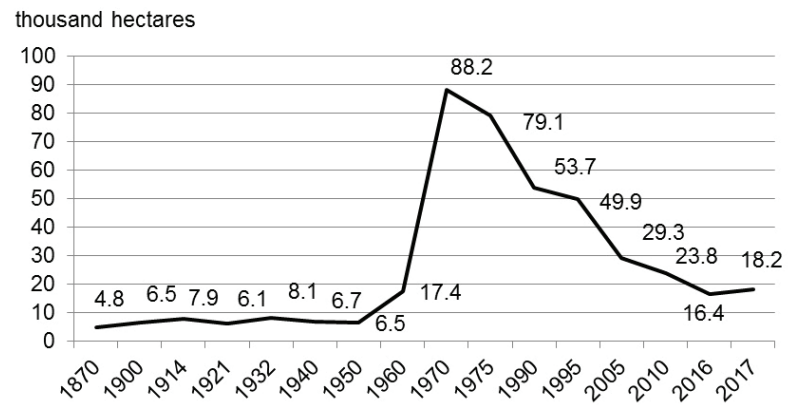

Figure 3. Dynamics of the productive vineyard area in Crimea in 1870-2017, thousand hectares

Source: Figure based on information from the Ministry of Agriculture of R. Crimea, 2017

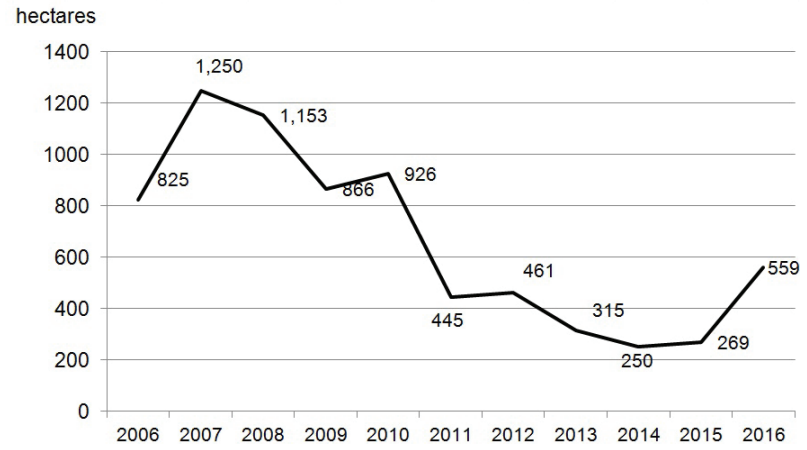

Figure 4. Planting of young vineyards in the Republic of Crimea in 2006-2016, hectares

Source: Figure based on information from the Ministry of Agriculture of R. Crimea, 2017

popular Italian and French varieties, selected by the 'Magarach' Institute of Viticulture and Winemaking, the varieties Bastardo Magarach, Early Magarach, Libya and Chocolate have become widespread. In recent years, many farms have started reviving the native grape varieties Kokur white, Kefesia, Sabbath and Asma (Tab. 2).

Under the European Convention, landscapes are understood as a common heritage of European identity resources. The vine landscapes play an important public role in cultural, ecological and social fields. They create a resource for economic activity, stimulate job creation, create a recognisable image of Crimea and contribute to the development of tourism. The vine landscapes of Crimea are a unique part of the landscapes of the region, and its cultural heritage, requiring systematic conservation and regeneration.

The reformation of the viticulture and winemaking sector in the Russian Federation. The number of economic entities has increased, but the process of the concentration of production and capital $v$ mergers and acquisitions is just beginning. During privatization, one of the largest wineries in Crimea - the Crimean factory of sparkling wines 'Novy Svet' - was transformed from a state enterprise into a joint-stock company, and in 2017 it was sold to the St. Petersburg company 'Southern project' (established by 'Russia' Bank).

The state has launched a programme to support viticulture and winemaking in Crimea. In 2014, state support amounted to 78.3 million rubles, in 2015 - 85 million rubles, in 2016 - 189.5 
Table 2. Grape varieties grown in the major viticulture zones of Crimea

\begin{tabular}{|c|c|c|}
\hline The main viticulture areas & Technical varieties of grape & Table varieties of grape \\
\hline South coast & $\begin{array}{c}\text { Cabernet Sauvignon, Aligoté, Rkatsiteli, Merlot, } \\
\text { Chardonnay, Sauvignon Green, Pinot Gris, Bastardo } \\
\text { Magarach, Saperavi, Traminer, Albillo Krimskii, } \\
\text { Verdelho, Sémillon, Tokaji, Shabash, Kokur white, } \\
\text { Muscat Blanc, Muscat Rose, Aleatico, Kefesia }\end{array}$ & $\begin{array}{c}\text { Moldova, Asma, Shabash, Red } \\
\text { Globe, PG-12 (Shokoladnii), Muscat } \\
\text { amber, Muscat Hamburg, Muscat Italy, } \\
\text { Magarach's Rannii, Cardinal }\end{array}$ \\
\hline Foothill & $\begin{array}{c}\text { Rkatsiteli, Cabernet Sauvignon, Merlot, Chardonnay, } \\
\text { Sauvignon Green, Rheinriesling, Aligoté, Pinot Gris, } \\
\text { Muscat Ottonel, Pinot Noir, Traminer, Bastardo } \\
\text { Magarach, Saperavi, Shabash, Kokur white }\end{array}$ & $\begin{array}{c}\text { Moldova, Muscat Hamburg, Muscat } \\
\text { amber, Muscat Italy, Magarach's } \\
\text { Rannii, Cardinal, Kodrjanka }\end{array}$ \\
\hline Steppe & $\begin{array}{c}\text { Aligoté, Cabernet Sauvignon, Rkatsiteli, Merlot, } \\
\text { Sauvignon Green, Rheinriesling, Chardonnay, Saperavi }\end{array}$ & $\begin{array}{c}\text { Magarach's Rannii, Cardinal, Moldova, } \\
\text { Muscat Hamburg, Muscat Italy, }\end{array}$ \\
& Arkadai, Odesskii souvenir, \\
& Karaburnu \\
\hline
\end{tabular}

Source: Table compiled by the authors based on materials from the Conception of Viticulture and Winemaking Strategy in the Republic of Crimea, 2014

million rubles, and in 2017 the subsidies amounted to 235 million rubles (Ministerstvo Sel'skogo Hozjajstva Respubliki Krym 2017). The main investments will be aimed at sowing new plantations of grapes.

In the context of sanctions against Russia will remain the main market for Crimean grapes and wines. However, in the long term, high-quality Crimean products can enter the world market.

The deterrent factors for the further development of viticulture in Crimea include intra-industry, intra-regional and external problems.

The most urgent problems of Crimean viticulture include:

- the disproportion of the modern vineyard area of Crimea to its potential. The sharp reduction of vineyard areas and the vintage volume of grapes has led to the dependence of the Crimean wine industry on imported wine materials;

- almost $50 \%$ of the vineyards are over 20 years old;

- in the transition from a planned economy to market relationships, the varietal composition of plantations has worsened, and grape growing technology has deteriorated. Poor use of resource-saving technologies and special agrotechnical measures aimed at increasing grape productivity has resulted in the relatively high cost of grape production;

- there is no nursery base in Crimea - the selection system has been destroyed;

- there is a deficiency of qualified personnel for viticulture and winemaking in the region.

The solution to these and other problems should become an integral part of the development strategy of viticulture and winemaking in the Republic of Crimea and Sevastopol. The Concept developed by the expert group of the Union of Vinegrowers and Winemakers of the Russian Federation includes the goal to create a wine-producing province in Crimea. Among the key objectives for the development of viticulture are: planting $60,000-70,000$ hectares of new vineyards, reaching a total vineyard area of 100 hectares by 2025 ; the replacement of table and technical grape imports to the Russian market $(20 \%$ and $30 \%$, respectively); creating nurseries for cultivating at least 15 million seedlings per year; organising an agricultural equipment park for processing grapes and industrial refrigerators for storing table grapes with a capacity of at least 40,000 tons of simultaneous storage.
The necessary organisational form for the future development of viticulture and winemaking is a wine cluster, as has been successfully implemented in several countries. It is important to develop and realise the models of several regional clusters, uniting the grape and wine enterprises and related organisations located in the same region and involved in a common business. Big brand businesses, lease-holders and medium and small enterprises, including farmers, can enter this cluster.

The successful development of viticulture in many countries shows the important role of state support. Taxation, credit and subsidies for the industry are preferential, as well as financing marketing activities and research aimed at improving the quality of grapes.

\section{Conclusion}

Crimea has a more than 2,000-year history of viticulture and winemaking. Reaching its heyday in the 1960 and 1970s, Crimean viticulture developed extensively; however, while the areas of the vineyards increased, their productivity did not. The 2000s saw the degradation of the vine landscapes in Crimea - that is, the reduction of vineyard areas, thinning out, and the reduction of yield due to the deterioration of the varietal structure of plants and cultivation technology violation. The reforming of the wine complex of Crimea must be based on a scientificallydeveloped strategy; the advanced organisational form is that of a regional wine cluster. The vine landscapes in Crimea are the cultural heritage of the region.

\section{Acknowledgements}

This research was carried out with the support of the Program for the Development of the Crimean Federal V.I.Vernadsky University for 2015-2024 years during the project "Academic Mobility Network "GIS-Landscape - Technologies and techniques for the formation of geoportals of present-day landscapes of regions" in 2017 year. 
MISCELLANEA GEOGRAPHICA - REGIONAL STUDIES ON DEVELOPMENT

Vol. 22 • No. 2 • 2018 • pp. 102-108 • ISSN: 2084-6118 • DOI: 10.2478/mgrsd-2018-0012

\section{References}

Akimtsev, VV 1946, 'Pochvy i vino', Vinodeliye $i$ vinogradarstvo SSSR (Winemaking and viticulture of the USSR), no. 6, pp. 7-14.

Avidzba, AM 2000, Agroekologicheskiye resursy kak osnova strategii vozrozhdeniya vinogradarstva Kryma (Agroecological resources as the basis for the strategy of revival of the viticulture of Crimea), Krym Press, Yalta.

Avidzba, AM \& Cheremisina, SG 2003, Ekonomika vinogradarstva Kryma: teoriya $i$ praktika funktsionirovaniya (Economics of wine growing of Crimea: the theory and practice of functioning), Adonis, Yalta.

Avtonomnaja Respublika Krym v 2002 g. Statisticheskij ezhegodnik (Autonomous Republic of Crimea in 2002. Statistical yearbook), 2003, Simferopol.

Blagonravov, PP \& Shcherbakov, PM 1963, Osvoyeniye gornykh sklonov pod vinogradniki (Development of mountain slopes for vineyards), Sel'khozizdat, Moscow.

Bolgarov, PT 1960, Vinogradarstvo (Viticulture), Krymizdat, Simferopol.

Buzni, NP 1929, Krymskoye vinogradarstvo i osnovnyye puti yego dal'neyshego razvitiya (Crimean viticulture and the main ways of its further development,), Krymizdat, Simferopol.

Council of Europe 2000, European Landscape Convention. Available from: <rus-eu-culture.ru/files/document/Eu-convlandshaft.doc>. [22 April 2018].

Davitaya, FF 1981, 'Osnovnyye printsipy rayonirovaniya kul'tury vinograda', Fiziologiya vinograda i osnovy yego vozdelyvaniya (Basic principles of zoning of grape culture', Ecology of grapes and bases of its cultivation), vol. 1, pp. 27-52.

Dikan, AP 2013, Na puti $k$ uspeshnomu vinogradarstvu (On the way to successful viticulture), Bisnes-Inform, Simferopol.

Dragan, NA 1990, Otsenka prigodnosti pochv pod vinogradniki (metodicheskiye rekomendatsii), Simferopol.

Dzhenev, SY \& Antipov, VP 1999, 'Realizatsiya rynochnykh printsipov khozyaystvovaniya - osnovnoy put' vozrozhdeniya vinogradorsko-vinodel'cheskogo kompleksa Ukrainy' (Implementation of market principles of management - the main way of revival of the wine-growing complex of Ukraine), Vinogradarstvo, vol. 30, pp. 5-11.

Fursa, DI 1977, Pogoda, orosheniye i produktivnost' vinograda (Weather, irrigation and grape productivity), Gidrometeoizdat, Moscow.

Istorija vinogradarstva v Krymu, 2018 (The history of viticulture in Crimea). Available from: <vinograd-crimea.com/history>. [22 April 2018].

Kazantseva, LP \& Fursa, DI 1985, 'Vliyaniye nekotorykh ekologicheskikh faktorov na urozhaynost' i sakharistost' vinograda', Ekologiya vinograda i urozhayev (The influence of some environmental factors on the yield and sugar content of grapes', Ecology of grapes and crops), pp. 58-61.

Khachaturyan, RP \& Gavrilov, GP 1985, 'Vliyaniye ekologicheskogo vinograda i urozhayev', Ekologiya vinograda i urozhayev (Influence of ecological grapes and crops',Ecology of grapes and crops), pp. 30-34.
Kontseptsiya strategii razvitiya otrasli Vinogradarstva i Vinodeliya $\checkmark$ Respublike Krym i gorode federalnogo znacheniya Sevastopol na period 2014-2025 gg (The concept of the Strategy of development of viticulture and winemaking in the Republic of Crimea and the city of Federal importance Sevastopol for the period 2014-2025). 2014, Simferopol.

Matchina, IG \& Buzni, AN 1999, 'Metodiki regional'nogo prognozirovaniya vinogradarsko-vinodelcheskogo proizvodstva', Region ('Methods of regional forecasting of viticulture and wine production', Region), no 2, pp. 55-57.

Ministerstvo Sel'skogo Hozjajstva Respubliki Krym 2017, Vinogradniki $i$ vinodelie (Ministry of agriculture of the Republic of Crimea 2017, Vineyards and winemaking), Simferopol.

Narodnoe hozjajstvo Krymskoj oblasti. Statisticheskij sbornik (National economy of the Crimean region. Statistical compendium), 1977, Tavrija, Simferopol.

Negrul, AM \& Krylatov, AK 1964, Podbor zemli i sortov dlya vinogradnikov (Selection of land and varieties for vineyards), Selkhozizdat, Moscow.

Petrova, EV (ed.) 2010, Krym ot drevnostidonashikh dney (Crimea from antiquity to the present day), ChernomorPRESS, Feodosiya, Koktebel, Simferopol.

Ponomarev, VF, Pargulov, SG \& Chernjavskij, AF 1975, Intensifikacija vinogradarstva Kryma (Intensification of viticulture in Crimea), Tavrija, Simferopol.

Pozachenyuk, KA (ed.) 2009, Sovremennyye landshafty Kryma $i$ sopredelnykh akvatoriy (Modern landscapes of the Crimea and adjacent water areas), Biznes-Inform, Simferopol.

Rybintsev, VA 1998, Vinograd i vino Ukrainy: istoriya, gosudarstvo (teoreticheskiye $i$ organizatsionno-ekonomicheskiye aspekty razvitiya) (Grapes and wine of Ukraine: history, state (theoretical and organizational-economic aspects of development), IAE, Kiev.

Skvortsova, AF \& Dragan, NA (eds.) 1990, Otsenka prigodnosti pochv pod vinogradniki (metodicheskiye rekomendatsii) (Assessment of the suitability of the soils under vines (guidelines), Simferopol.

UNESCO 1972, Convention concerning the Protection of the World Cultural and Natural Heritage. Available from: <http:// whc.unesco.org/archive/convention-en.pdf>. [22 April 2018].

Ved', IP 2003, Klimaticheskiy atlas Kryma, Krymuchpedgiz, Simferopol.

Zaharova, OJu 2005, Svetlejshij knjaz' M.S. Voroncov (His serene Highness Prince M. S. Vorontsov,), Biznes-Inform, Simferopol. 